\title{
Analisis Perilaku Peserta Didik Slow Learner (Studi Kasus Di MTsN Makassar)
}

\author{
Ratika Nengsi $^{\mathrm{a}, 1}$, Abdul Malik ${ }^{\mathrm{a}, 2}$, Andi Fadilah A Natsir ${ }^{\mathrm{a}, 3}$ \\ aUniversitas Muslim Indonesia \\ 1'ratika.nengsi@umi.ac.id, 2abdul.malik@umi.ac.id, ${ }^{3}$ andifadhilahnatsir@umi.ac.id
}

\begin{abstract}
Abstrak
Kajian tentang kesulitan belajar peserta didik dalam pembelajaran adalah hal penting untuk memberikan pendidikan yang sesuai dengan kebutuhan, hasil penelitian yang telah di laksanakan, maka peneliti dapat menyimpulkan hasil deskriptif penelitiannya dalam dua hal, yaitu perilaku siswa yang mengalami slow learner dalam pembelalajaran adalah lambatnya peserta didik slow learner dalam memahami suatu materi yang dijelaskan membutuhkan waktu yang lebih lama dibandingkan dengan temannya yang lain sehingga target-target pencapaian pembelajaran ada yang tidak dapat tercapai. Selain itu kefokusan dari peserta didik slow learner yang sulit dan membutuhkan waktu untuk membuat fokus di awal pembelajaran. efektivitas strategi yang digunakan guru dalam mengatasi slow learner pada peserta didik MTsN Makassar adalah guru melakukan pembelajaran kelompok, melakukan tutor sebaya antar peserta didik, pemberian penguatan, pendekatan khusus seperti privat khusus, pemberian nasehat dan motivasi kepada peserta didik yang mengalami slow learner. Adapun faktor pendukung yang di rasakan oleh guru dalam mengatasi slow learner pada peserta didik, yaitu ikatan yang terjalin antar peserta didik sangat baik, sehingga memudahkan guru dalam melakukan strateginya. Selain itu kemauan belajar dan partisipasi dari peserta didik itu sendiri yang menjadi salah satu faktor pendukung. Selain faktor pendukung ada pula faktor penghambat yang di hadapi oleh guru dalam mengatasi slow learner pada peserta didik di MTsN Makassar, yaitu keterbatasan waktu.
\end{abstract}

Kata Kunci : Stratagi Guru, Peserta didik, slow learner

\section{Pendahuluan}

Perbedaan individual yang ada pada peserta didik dalam kelas harus menjadi perhatian bagi guru. Dalam perbedaan itu ada peserta didik yang cepat, sedang dan lamban. Dalam menjalankan tugas mengajar guru tidak boleh hanya focus pada peserta didik yang pintar saja dan sebalinya guru tidak boleh hanya focus pada siswa yang lamban saja karena hal tersebut mampu menjadi penyebab turunnya motivasi belajar peserta didik di kelas.

Pendidikan merupakan sesuatu hak semua orang, anak-anak, remaja dan orang dewasa, lakilaki maupun perempuan, anak normal bahkan yang berkebutuhan khusus. Semua orang berhak mengembangkan potensi kemanusiaannya untuk menjadi manusia yang utuh melalui pendidikan. Hal ini juga sesuai dengan konsep dalam pendidikan untuk semua (education for all). Salah satu komponen penting dalam mencapai tujuan pendidikan tersebut adalah guru. Guru adalah faktor yang menentukan dengan peran yang sangat dominan dalam pendidikan pada umumnya, karena guru memegang peranan dalam proses pembelajaran, dimana proses pembelajaran merupakan inti dari proses pendidikan secara keseluruhan. Seorang guru harus mampu menyelesaiakan segala kesulitankesulitan yang dihadapi oleh anak didik dalam pelaksanaan pembelajaran sehingga hal itu menyebabkan upaya guru dalam melakuka pendekatan pada anak didiknya lebih mendalam. Karena, tanpa pemahaman guru pada individu anak akan menyebabkan putusnya komunikasi verbal dan nonverbal anak. Di samping itu juga terdapat anak yang lamban (slow) dalam belajar. Setelah melihat uraian latar belakang di atas maka rumusan masalah dalam penelitian ini adalah: "Bagaimana perilaku belajar peserta didik Slow Learner di Madrasah Tsanawiyah Negeri Makassar?" 


\section{Tujuan Penelitian}

Penelitian ini bertujuan untuk mengidentifikasi dan menganalisa perilaku belajar peserta didik Slow Learner di Madrasah Tsanawiyah Negeri Makassar studi Pendidikan Agama Islam.

\subsection{Luaran Penelitian:}

a. Bahan penyusunan strategi dan perencanaan pembelajaran

b. Buku ajar bidang studi khususnya Pendidikan Agama Islam

c. Jurnal Nasional

d. Referensi penelitian mahasiswa

Bersama untuk mencapai tujuan pendidikan yang ditujukan bagi semua peserta didik, begitu juga secara khusus di MTs Negeri Makassar.

Hal inilah yang membuat peneliti merasa perlu melakukan penelitian untuk mendapatkan informasi yang lebih lengkap dengan merumuskan judul penelitian "Analisis Perilaku Belajar Peserta Didik Slow Learner Dan Strategi Penanganannya (Studi Kasus di MTsN Makassar)".

\section{Tinjauan Pustaka}

\subsection{Slow Learner}

\section{a. Pengertian Slow Learner}

Keberadaan Slow Learner selalu ditemukan hampir dalam setiap kelas pembelajaran, ketidak samaan kemampuan anak dalam menangkap pembelajaran menjadi perhatian khusus guru. Tidak hanya perbedaan pada fisi tapi juga psikis. Karena anak yang mengalami Slow Learner tidak sama dengan anak normal oada umumnya.

Salah satu ahli yakni Burton mengemukakan bahwa anak Slow Learner adalah anak dengan tingkat penguasaan materi yang rendah, padahal materi tersebut merupakan prasyarat bagi kelanjutan di pelajaran selanjutnya, sehingga sering harus mengulang. Fransle dan R. Gulliford mendefenisikan murid lambat belajar karena suatu kondisi-kondisi terbatas yang mengakibatkan keterlambatan pendidikan. Anak lambat belajar terklasifikasi dengan kualitas kognitif/IQ berkisar antara 70 sampai 90. Maka dari itu sebagaimana yang dikemukakan oleh ke dua ahli tersebut disimpulkan bahwa anak yang mengalami Slow Learner memiliki IQ berkisar 70- 90 dan memiliki kekurangan dalam memahami materi.

\section{b. Ciri-ciri Anak Slow Learner}

1) Berfungsinya untuk kemampuan kognisi, pada bawah level normal.

2) Biasanya tidak matang pada kemampuang komunikasi interpersonal

3) Sulit dalam mengikuti arahan-arahan yang memerlukan banyak arahan atau strukturnya.

4) Biasanya hanya perhatikan hal-hal saat ini saja dengan tidak jelasnya tujuan jangka panjang

5) Hanya punya sedikit strategi internal, misalnya kemampuan organisasional juga kesulitan dalam belajar serta menggeneralisasikan informasi.

6) Mendapatkan nilai yang kurang baik dalam prestasi dan hasil belajarnya.

7) Dapat bekerja dengan baik dalam hand - on materials, yaitu materi-materi yang telah dipersingkat dan diberikan pada anak, seperti kegiatan di laboratorium dan kegiatan manipulatif.

8) Memiliki self-image dan kepercayaan diri yang buruk.

9) Mengerjakan tugas dengan lamban

10) Memiliki keterampilan yang lambat bahkan kurangnya penguasaan pada keterampilan yang seharusnya dimiliki

11) Memiliki daya ingat yang memadai, tetapi mereka lambat mengingat

\section{c. Faktor-Faktor Yang Mempengaruhi Anak Slow Learner}

Slow Learner memiliki hubungan yang sangat erat dengan IQ, maka terdapat dua faktor yang mempengaruhinya : 
1) Internal

a) Genetik / Hereditas

Dari beberapa penelitian yang membahas tentang hereditas pada sebuah survey kepustakaan dunia mengenai persamaan kemampuan intelegensi manusia dalam ruang lingkup keluarga, Atkinson mengemukakan bahwa ada korelasi antara beberapa faktor yakni Faktor IQ yang dimiliki orang tua dengan keturunannya. Maka, kesimpulannya adalah semakin tinggi proporsi dua anggota keluarga gen serupa pada 2 anggota keluarganya, maka semakin tinggi korelasi rata-rata intelegensi (IQ) mereka.

\section{b) Biokimia}

Hal lain yang menyebabkan adalah adanya pengaruh dari zat-zat yang mampu merusak otak anak, seperti: zat pewarna dalam makanan, lingkungan yang tercemar, komsumsi pada makanan yang mengandung zat berbahaya, pemakaian zat kimia pada pemakaian kosmetik sehingga diserap dalam tubuh, pemeriksaan gizi yang tidak begitu diperhatikan serta pengaruh sosial psikologis.

Terdapat komponen fungsi otak yang berbeda kecepatan dan laju yang berbeda pula, dengan fungsi periodic laju pertumbuhan tercepat dan tingkat kerentanan terbesar terhadap pengaruh negatif. Pada saat anak lahir, anak memiliki cakupan otak $10 \%$ dari jumlah berat badannya dan seterusnya.

\section{2) Faktor Eksternal}

a) Lingkungan

Pengaruh lingkungan memberikan dampak pada peningkatan IQ anak, dari beberapa penelitian Beyley memberikan kesimpulan bahwa kedudukan sosial dan ekonomi keluarga memberikan pengaruh pada kemampuan IQ anak. Anak yang memiliki IQ sekitar 65 jika berada dilingkungan yang miskin, artinya kemiskinan menjadi salah satu faktor yang menjadi penentu tinggi randahnya IQ anak. Sedangkan, lebih dari 100 IQ yang dimiliki anak berada pada lingkungan yang sedang atau kaya. Pada kesimpulan hasil penelitian ini menjelaskan kondisi bagaimana pola asuh anak mereka.

Masalah yang ditemukan dihadapi oleh anak slow learner dalam beberapa penelitian menunjukkan bahwa rupanya anak slow learner mengalami beberapa masalah belajar serta tingkah laku disebabkan minimnya kemampuan dan terbatasnya potensi intelektuan yang dimilikinya. Hal tersebut menjadi penyebab kurangnya kondisi psikis untuk memahami dirinya dan orang lain. Karande, dkk. (Arjmandnia dan Kakabaraee, 2011: 88) mengemukakan masalah umum slow learner (anak lamban) belajar yang ditemukan guru dalam pembelajaran di antaranya:

(1) Kondisi yang dimiliki prestasi rendah di semua mata pelajaran;

(2) Kemampuan lemah dan memiliki kesulitan dalam membaca, menulis, atau matematika;

(3) mempunyai daya ingat rendah; dan

(4) kondisi hiperaktif (kurang memperhatikan.)

Masalah belajar pada anak lamban belajar disebabkan oleh penyebab yang tidak dapat diamati segera (unobservable) (Mumpuniarti, 2007: 1). Penyebab tersebut berhubungan dengan kekuatan berpikir dan kemampuan belajar (Sangeeta Chauhan, 2011: 280). Malik, Rehman, dan Hanif (2012: 136). Menurut Piaget anak berkembang dengan frekwensi yang sama namun terjadi perbedaan pada perkembangan dalam proses kecepatan. Perkembangan kognitif dikelompokkan menjadi empat tahapan usia yaitu 0-2 tahun merupakan sensory motor yaitu perkembangan kognitif, 2-7 tahun merupakan tahap pra operasional, 7-11 yahun merupakan tahap concrete-operational dan 11-15 tahun yang merupakan formal operasional.

\section{Metode Penelitian}

\subsection{Jenis dan Pendekatan Penelitian}

Jenis penelitian ini adalah Kualitatif dengan Pendekatan Studi Kasus (case Study). Sebuah penelitian lapangan yang akan mengkaji fenomena berkaitan dengan permasalahan yakni anak yang mengalami slow learner. 


\subsection{Lokasi dan waktu penelitian}

Lokasi penelitian ini dilakukan di Madrasah Tsanawiyah Negeri Makassar yang dilakukan selama 6 bulan penelitian. Lokasi penelitian tersebut adalah salah satu Madrasah Tsanawiyah yang diminati oleh masyarakat khususnya di Makassar, lokasi yang strategis.

\subsection{Populasi dan Sampel Penelitian}

Dalam penelitian kuantitatif lebih ditekankan pada pengembangan wawasan dan keluasan informasi bukan kedalaman seperti pada penelitian kuantitatof yang menguji sesuatu dan melahiat pengarunya. Sehingga untuk pengambilan populasi dan sampel yang banyak perlu difokuskan pada sampel yang memenuhi kriteria pemenuhan datanya. Selanjutnya data yang diteliti adalah data dari sampel yang diambil dari populasi tersebut dengan teknik probability sampling (random). Dari data sampel tersebut kemudian akan di generalisasi (kesimpulan sampel diberlakukan untuk populasi)

Maka sampel dalam penelitian ini diambil dengan teknik purposive random sampling yakni peserta didik yang teridentifikasi sebagai anak yang mengalami Slow Learner pada Madrasah Tsanawiyah Negeri Makassar

\subsection{Instrument Penelitian}

Dalam penelitian $\mathrm{ku}$ instrument penelitian berkenaan dengan validitas dan reabilitas instrument dan cara-cara yang digunakan untuk mengumpulkan data. Dalam penelitian ini ada beberapa instrument penelitian yang digunakan yaitu sebagai berikut:
a. Observasi
1) Observasi deskriptif
2) Observasi terfokus
3) Observasi terseleksi
4) Interview (Wawancara)

\section{b. Dokumentasi}

\subsection{Teknik Analisis Data}

Dalam menganalisis data hasil penelitian memerlukan teknik untuk membuat data yang telah didapatkan itu bisa ditampilkan sesuai dengan kebutuhan informasi yang dibutuhkan.

Menganalisis data merupakan sebuah proses dan kegiatan yang mencari serta melakukan penyusunan secara terstruktur, data itu kemudian telah diperoleh berdasarkan hasil observasi, wawancara dan dokumentasi serta beberapa catatan lapangan yang digunakan sebagai instrument dan teknik pengumpulan data dalam penelitian ini. Selanjutnya data yang dikumpulkan kemudian dianalisis dengan maksud dan tujuan agar data yang didapatkan dapat dipahami dan mampu menjadi bahan bacaan dan informasi bagi orang lain.

Mengnalisis data dari hasil penelitian bisa dilakukan dengan mengorganisasikan data sesuai dengan kelompok data yang dijabarkan di setiap bagiannyanya, menyusun dan melakukan proses sintesa serta membuat pola dan menentukan data mana yang bisa dianggap penting dalam menyusun sebuah kesimpulan yang bisa diinformasikan kepada orang lain melalui tulisan dan publikasi dapat diceritakan kepada orang lain. Analisis data kualitatif adalah jenis penelitian yang datanya dianalisis berbersifat induktif, yaitu suatu analisis berdasarkan data yang diperoleh, selanjutnya dikembangkan pola hubungan tertentu atau menjadi hipotesis.

\section{a. Langkah Analisis Data}

Dalam sebuah penelitian proses analisis data dilakukan ketika sebelum memulai penelitian lapangan meggunakan data dari hasil observasi awal, penelitian kualitatif sendiri memberikan status kepada penelitinya sebagai key instrument. Proses analisis data lebih memfokuskan pada proses penelitian lapangan bersama dengan proses pengumpulan data. Metode analisis data menggunakan sesuai dengan Huberman \& Miles yakni Tri Angulasi Data yang terdiri dari reduksi data, penyajian data, dan penarikan kesimpulan. 
Proses menganalisis data yang dilakukan selama di lapangan dengan menggunakan model Miles dan Huberman dalam bukunya oleh Sugiyono mengatakan bahwa dalam kegiatan dan aktivitas menganalisis data kualitatif dilaksanakan dengan interaktif serta berlangsung selama berkelanjutan hingga datan yang dibuthkan didapatkan serta datanya sudah jebuh. Kemudian aktivitas menganalisis data ialah langkah-langkah yang diterapkan. Langkah tersebut adalah data reduction, data display, dan conclusion drawing/verification.

\section{1) Data Reduction (Reduksi Data)}

Mereduksi data maknanya adalah membuat rangkuman dan memilah hal yang pokok serta memfokuskan pada hal yang penting pada proses pemenuhan datanya. Menentukan tema serta pola dan membuang data yang dianggap tidak dibutuhkan dalam penyusunan hasil penelitian tujuan yang paling utama dari penelitian kualitatif adalah temuan.

\section{2) Data Display (Penyajian Data)}

Menyajikan data hasil penelitian dapat dilakukan dalam bentuk menguraika secara singkat, membuat bagan, hubungan antara kategori, flowchart, dan yang sejenisnya. Dengan menampilkan data maka bida mempermudah dalam memahami apa yang digambarkan sebagai suatu kejadian dari hasil penelitian yang selanjutnya melanjutnya berdasarkan semua yang telah dipahami.

\section{3) Conclusion Drawing / Verification}

Data yang telah direduksi dan ditampilkan kemudian disimpulkan dalam sebuah rumusan yang akan menjawab rumusan yang telah ditetapkan sejak awal, tetapi bisa juga tidak. Dari kesimpulan yang ada dalam penelitian kualitatif diharapkan sesuatu yang merupakan hasil temuan baru yang sebelumnya belum pernah ada ditemukan.

\section{Hasil Penelitian}

\subsection{Perilaku Belajar Peserta Didik Slow Learner di MTs Negeri Makassar}

Dalam penelitian yang dilaksanakan menggunakan instrument penelitian salah satunya adalah observasi/pengamatan, maka data yang ditemukan berdasarkan hasil observasi berkaitan dengan temuan masalah perilaku belajar peserta didik Slow Learner adalah sebagai berikut:

\section{a. Intelektual di bawah rata-rata}

Berdasarkan hasil penelitian dengan mengidentifikasi perilaku belajar peserta didik yang slow learning ditemukan bahwa, anak slow learner memiliki potensi intelektual yang sedikit lebih rendah dibandingkan anak normal lainnya, meskipun keberadaan mereka satu diantara sekian banyak anak di sekolah atau dilingkungannya. Berdasarkan hasil tes intelegensi yang dilakukan pihak sekolah anak yang diidentifikasi slow learner ini memiliki IQ 70-80. Dalam aktivitas belajarnya anak slow learner memiliki penguasaan materi yang rendah. Informasi ini didapatkan dari lokasi penelitian yang berkaitan dengan anak yang slow learner mengalamai kesulitan dan lamban hamper pada semua mata pelajaran terutama pada hafalan dan pemahamam.

Anak yang slow learner ini membutuhkan waktu yang cukup lama dalam memahami serta berulang-ulang untuk menyelesaikan tugasnya. Dalam perilaku belaajr sehari-hari di sekolah ini tentunya membuat mereka mendapatkan kesulitan, karena berada di tengah-tengah teman sebaya yang memiliki kecepatan belajar yang lebih, hal itulah yang menjadi salah satu faktir lemahnya self confidence dari anak. Seperti yang ditemukan di lokasi penelitian yakni di MTs Negeri Makassar. Ahli psikologi telah mengindikasikan bahwa kelemahan anak memiliki kemampuan intelektual di bawah rat-rata (intelelectual ability). Dengan banyak penelitian yang yang menunjukkan bahwa faktor keturunan bukan satu-satunya penyebab keterbelakangan anak tetapi pun dipengaruhi oleh lingkungannya.

\section{b. Lemah dan lambat dalam membaca materi pembelajaran}

Salah satu ciri anak yang Slow Learner adalah memiliki kemampuan membaca yang lemah dan lamban. Hasil pengamatan dalam penelitian ini ditemukan data tentang anak slow learnig dalam pembelajaran termasuk dalam kategori lamban dalam membaca materi yang diberikan oleh guru. Anak inisial UAQ dalam proses pembelajaran menundukkan kepalanya dan melihat teman sebaya dalam kelas ketika mengalami kelelahan dalam membaca bahan ajar yang disajikan. Lemahnya 
kemampuan membaca juga disertai dengan permasalahan artikulasi. Maka dalam pembelajaran peserta didik yang mengalami slow learning diberikan waktu tambahan dengan di dikte selain itu memiliki kemampuan menilis yang buruk sehingga kata yang hendak ditulis menjadi kurang lengkap. Lemahnya kemampuan artikulasi menjadi penyebab ketidak percayaan mereka pada penerimaan teman-temannya karena ejekan yang diberika. Maka dari itu berdasarkan hasil observasi yang di temukan anak yang mengalami slow learning cendrung lebih pendiam dan mengasingkan diri sendiri. Slow learner mengalami gagal memahami perintah yang bersifat verbal, seringkali anak yang mengalami hal ini ketika diberi sebuah pertanyaan. Anak slow learner lebih menyukai ketika diberi pertanyaan dengan sifat nonverbal jika tidak maka mereka akan menjawab dengan jawaban yang tidak sesuai dengan pertanyaan.

\section{c. Cenderung pendiam dan Cepat merasa bosan dalam belajar}

Bosan dalam pembelajaran bias dialami oleh setiap anak, akan tetapi dalam keadaan yang dipengaruhi oleh factor internal dan eksternal. Peserta didik yang mengalami Slow Learner memiliki rasa percaya diri yang rendah karena rasa minder dan malu karena mereka menyadari memiliki kemampuan akademik yang kurang baik dan mereka selalu mendapatkan nilai yang di bawah ratarata.

\section{d. Senang menggambar}

Kebutuhan setiap anak dalam belajar memang berbeda pada tiap individu anak. Ada anak yang suka jika tampil berbicara, mendemonstrasikan, membaca, menganalisis, menggambar. Hal itu memerlukan kreativitas guru untuk menggunakan media pembelajaran yang tepat. Bagi anak yang mengalami Slow Learner memang memerlukan pendekatan dan mendalaman karakter yang dalam.

\section{e. Sulit berkomunikasi dengan teman dalam pembelajaran}

Karena anak yang slow leaner memiliki kemampuan lemah dan hasil belajar rendah mengakibatkan rasa rendah diri yang tinggi, sehingga tidak bias menjalin komunikasi dengan teman sebaya dalam kelas. Tidak mampu menyimak materi yang berupa symbol

Pembelajaran disekolah tidak semuanya bersifat konseptual, teoritis tp juga dalam pembelajaran tertentu materi ajarnya adalah huruf dan symbol seperti Matematika, dan Fisika.

Salah satu guru yang harus menyiapkan metode lain dari pembelajarannya adalah Guru Mata Pelajaran Matematika dan Fisika, karena F sebagai anak yang mengalami Slow Learner sangat kesulitan dalam memahami materi dari guru tersebut, maka dari itu guru harus menyiapkan strategi khusus untuk F, juga untuk teman sebaya $\mathrm{F}$ agar tidak ketinggalan materi dalam menunggu remedial F.

\section{f. Emosi kurang stabil}

Anak Slow Learner memiliki emosi yang kurang stabil, serta sensitive. Anak ini sangat gaampang menangis jika diajak bicara atau bermain apa lagi dengan hal yang tidak sesuai dengan keinginannya.

\section{Kesimpulan Dan Saran}

\subsection{Kesimpulan}

Dari uraian hasil pembahasan penelitian maka kesimpulan dalam penelitian ini adalah:

a. Perilaku belajar yang dialami peserta didik slow learner di MTsN Makassar adalah:

1) Lambat membaca dan lemah dalam memahami bahan ajar

2) Pemalu dan kurang percaya diri

3) Sulit berkomunikasi dengan teman sebaya di kelas

4) Rendahnya motivasi belajar

5) Hasil belajar yang rendah

6) Prestasi belajar buruk

7) Kurang memahami symbol

8) Emosi kurang stabil 
b. Stategi guru dalam mengatasi kesulitan belajar peserta didik Slow Learner

1) Memberi perhatian

2) Pengulangan materi

3) Memberikan apersepsi

4) Menyiapkan alat peraga dan media yang bervariasi

5) Perlakuan khusus dalam memberikan informasi

6) Penjelasan tujuan pembelajaran khusus

7) Menyampaikan materi ajar (pokok) pembahasan dengan bagan dan gambar

8) Memberi latihan dan praktik

9) Pemberian contoh dan noncontoh

10) Melibatkan peserta didik untuk berpartisipasi

11) Memberi waktu tambahan

12) Menjalin komunikasi dengan orang tua peserta didik 


\section{DAFTAR PUSTAKA}

Ahmadi Abu. Psikologi Umum. Jakarta : Rineka Cipta, 2009.

A, Jenkins. dkk, Teaching In Higler Education. New York : Abigon, 2007.

Atwi Suparman, M. Desain Intruksional Modern Panduan Para Pengajar dan Inovator Pendidkan. Jakarta : Erlangga, 2012.

A, Pribadi, Benny. Model Desain Sistem Pembelajaran. Jakarta : PT. Dian $\quad$ Rakyat, 2011.

Hadi, Ahmad \& Haryono. Metodologi Penelitian Pendidikan. Bandung : Pustaka Setia, 2005.

Hamalik, Oemar. Proses Belajar Mengajar. Jakarta : PT. Bumi Aksara, 2008.

Kunandar. Langkah Mudah Penelitian Tindakan Kelas sebagai Pengembangan Profesi Guru. Jakarta : Rajawali Pres, 2008.

Nata, Abuddin. Ilmu Pendidikan. Jakarta : Kencana, 2009.

. Persfektif Islam Tentang Strategi Pembelajaran. Jakarta : Kencana, 2009.

Nasution, S. Berbagai Pendekatan dalam Proses Belajar dan Mengajar. Jakarta : PT. Bumi Aksara, 2009.

Mardapi, Djamari. Teknik Penyusun Instrumen Tes dan Non Tes. Jogjakarta : Mitra Cendikia Offset, 2008.

Rusman. Model-Model Pembelajaran Mengembangkan Profesional Guru. Jakarta: Rajawali Pres, 2013.

Suprijono, Agus. Cooperative Learning. Yogyakarta : Pustaka Belajar, 2013.

Sudjiono, Anas, Pengantar Statistik. Jakarta : Rajawali Pres, 2012.

Suryarata, Sumadi. Metodologi Penelitian. Jakarta : PT. Grafindo Persada, 2013 